\title{
Predatory Preferences and External Anchors: The Political Sources of European Imbalances
}

\author{
Ton Notermans \\ Department of International Relations, \\ Tallinn University of Technology \\ Akadeemia tee 3 , \\ Tallinn 12618, Estonia \\ E-mail: ton.notermans@tseba.ttu.ee
}

\begin{abstract}
The economic imbalances that caused the euro crisis are essentially political in nature as they result from both hard- and softcurrency countries seeking to avoid addressing fundamental policy inconsistencies. The hard-currency mercantilism of Germany and its smaller neighbours is inherently vulnerable to currency appreciation and thus needs to lock its main trading partners into a fixed exchange rate in order to survive. The lack of an inclusionary post-war settlement meant that soft-currency countries were progressively unable to contain distributional conflicts without a fixed exchange rate anchor. As a result, wage costs came to diverge rapidly under the common currency thereby contributing to massive current account imbalances. Apart from the economic issue of whether balance should best be restored by internal or external devaluation, the more important question may be whether eurozone nations are politically able to implement regimes that depend neither on external anchors nor on mercantilist current account surpluses.
\end{abstract}

Keywords: Economic and Monetary Union, euro crisis, European imbalances, European Integration, Germany 
Few would have predicted it sixty years before, but the twenty-first century might yet belong to Europe." (Judt, 2007, p. 800)

"No, I do not see the EU as an inspiration for the world. I see it as an undertaking that was ill designed due to too rapid expansion and that will probably fail." (Lee Kuan Yew, quoted in 'Wie Chinesisch wird die Welt?' Zeit-Online, 6 September 2012)

\section{Introduction}

The root cause of the current euro crisis were massive payments imbalances, with many peripheral countries in Southern Europe running current account deficits financed by capital inflows from the core countries. The common currency itself played a significant role in the build-up of these imbalances as it promoted capital flows to the periphery by removing the risk of devaluation, whereas the inability of the periphery to devalue in turn meant that core countries could exploit their institutional advantage in wage setting to significantly increase their price competitiveness (Flassbeck, 2009, p. 66ff; Joebges, 2010). In Germany, for example, the average annual current account surplus increased from 0.47 per cent of GDP in 1988-1998 to 3.64 per cent in 1999-2011.

Although the introduction of the euro did bring the problem to a head, current account imbalances within the EU have shown a fairly stable pattern almost since the 1960s, with Germany, for example, only recording deficits on two occasions, namely in the wake of the second oil price crisis and after unification, whereas the Greek and Spanish accounts were in surplus for only 11 and 12 years, respectively, since $1960 .{ }^{1}$ A durable adjustment of the traditional patterns of current account balances within the EU will thus be necessary if the stability of inter-European (economic) relations is to be safeguarded. Indeed, the EU itself has realised as much with the introduction of an Excessive Imbalances Procedure (EIP).

However, the core problem is that these imbalances are the result of deficit and surplus countries seeking refuge in a common currency in response to an inability to address fundamental policy inconsistencies. The hard-currency mercantilism pursued by Germany and its small neighbours is inherently vulnerable to currency revaluation. In a world in which the majority of trading partners has a preference for looser monetary policy, a priority for tight money should lead

1 Source: all current account figures AMECO. 
to currency appreciation and thereby eliminate current account surpluses. Hardcurrency mercantilism in the end can survive only if the main trading partners adopt similar monetary preferences while refraining from devaluation, which of course has been the core of all German proposals for monetary integration, from Chancellor Brandt's 1996 proposals for Economic and Monetary Union (EMU) to the design of the common currency (Henning, 1994, Ch. 5).

Yet, in a fixed exchange rate arrangement with countries that have different wage setting dynamics, such preferences become predatory as the accumulation of imbalances since the introduction of the euro has shown. The problem has been familiar to Western Europe since the 1960s when, for example, Italy and France devalued occasionally in order to restore competitiveness. That the peripheral countries nevertheless agreed to the German design for monetary union was the result of their own inability to address domestic distributional conflicts. A fixed exchange rate, and later the common currency, here served the function of an external anchor to deeply fragmented and politicised industrial relations.

What has been lost from sight in the discussion about economic strategies to overcome the euro crisis (Weisbrot \& Ray, 2011; Krugman, 2012), is that in view of the deep roots these imbalances have in the core and peripheral countries, durable current account reversals may be politically more problematic than commonly assumed. ${ }^{2}$ Given that competitiveness is considered the key to growth and prosperity, for the surplus countries the main issue is that a successful (internal or external) devaluation strategy of the GIIPS ${ }^{3}$ countries which eliminates their current account surplus may easily be interpreted as a beggar-thy-neighbour strategy. For the Southern eurozone countries the issue of current account adjustment is even more problematic. The economic and social costs of the current internal devaluation strategy carry the clear risk that the polity will disintegrate and anti-EU majorities will form. But a strategy of external devaluation would rob the southern eurozone periphery of the external constraint, which was the reason they took flight in the euro in the first place.

The paper proceeds as follows: Section Two argues that the root of the common currency lie in a mutual desire by core and peripheral countries to avoid addressing domestic inconsistencies. Section Three speculates about the political feasibility of a durable current account reversal in Germany. Section Four provides the conclusion.

2 A notable exception is Bonatti \& Fracasso, 2012.

3 Greece, Italy, Ireland, Portugal, Spain. 


\section{Mercantilists and Anti-Mercantilists in Europe}

At least since the return to convertibility in 1959, the exchange rate policies of West-European countries can be divided into three groups. The "hard-currency" group, comprising Germany, the Netherlands, Belgium and Austria, was averse to using currency devaluation to prop up domestic growth. With the partial exception of Austria, where the so-called Austro-Keynesianism had taken hold, the idea that growth depended on macroeconomic policies had never taken root. Instead, growth was interpreted as an issue of competitiveness and wage costs. Devaluation in this view was unnecessary if wage constraint was forthcoming and counter-productive if it was not. The political underpinning was formed by a political system in which Christian democrats were either dominant or held the balance with social democratic parties and a labour constituency in both parties. Based on such a strategy all four countries ran virtually uninterrupted current account surpluses during the Bretton Woods system (Table 1).

Table 1. Average annual current account balance (\% of GDP)

\begin{tabular}{|l|r|r|r|r|r|}
\hline Country & \multicolumn{1}{|c|}{$\begin{array}{l}\text { Average } \\
\text { 1960-2011 }\end{array}$} & $\begin{array}{l}\text { Average } \\
\text { 1960-73 }\end{array}$ & $\begin{array}{l}\text { Average } \\
\text { 1974-84 }\end{array}$ & $\begin{array}{l}\text { Average } \\
\text { 1985-2011 }\end{array}$ & $\begin{array}{l}\text { Average } \\
\text { 1999-2011 }\end{array}$ \\
\hline Austria & -0.52 & 0.03 & -2.61 & 0.05 & 2.06 \\
\hline Belgium & 1.81 & 1.39 & -1.38 & 3.32 & 3.64 \\
\hline Germany & 1.57 & 0.82 & 0.63 & 2.35 & 3.64 \\
\hline Luxembourg & 11.54 & 8.17 & 15.80 & 11.56 & 9.12 \\
\hline Netherlands & 3.46 & 1.29 & 2.80 & 4.85 & 6.13 \\
\hline Denmark & -0.63 & -2.16 & -3.49 & 1.32 & 3.21 \\
\hline Sweden & 1.93 & 0.63 & -0.67 & 3.66 & 6.52 \\
\hline United & & & & & -2.25 \\
Kingdom & -1.06 & 0.16 & -0.28 & -2.00 & -12.25 \\
\hline Greece & -3.77 & -1.68 & 0.62 & -6.64 & -5.68 \\
\hline Spain & -2.21 & -0.33 & -1.70 & -3.39 & -0.40 \\
\hline France & -0.29 & 0.42 & -1.31 & -0.25 & -1.23 \\
\hline Italy & -0.03 & 1.36 & -0.73 & -0.47 & -9.67 \\
\hline Portugal & -6.60 & -2.64 & -9.26 & -7.56 & \\
\hline
\end{tabular}

${ }^{1}$ Figures up to 1990 refer to West Germany only

Source: AMECO, own calculations

In Scandinavia and the United Kingdom instead, the concept that growth did depend on discretionary macroeconomic management had taken stronger root, 
and, accordingly, the exchange rate would be adjusted in case of a conflict between external and internal balance. The political underpinning of this model was a dominant Labour party linked to a strong trade union movement. During the Bretton Woods period, the current account positions of this group were moderately negative for the UK and Denmark and positive for Sweden.

The third group consists of Spain, France, Greece, Portugal and Italy. Here the political system was much more polarised with Christian democrats facing communist parties in the democratic countries, whereas right-wing dictatorship ruled in Spain and Portugal until 1976 and 1974, respectively, while Greece was under military rule from 1967 to 1974. All countries on average were in current account deficit during the Bretton Woods period, although the deficit was very moderate for Italy and rather substantial for Portugal.

Since the mid-seventies all these systems have come under stress as the combined result of the questioning of the post-war political settlement and the radicalisation of the European Left, as well as the two oil price shocks. The initial reaction was rather similar in most countries and consisted of an attempt to exchange voluntary wage restraint for an expansionary fiscal policy and other measures dear to the heart of the trade unions. The success of such policies largely depended on the structure of industrial relations, with the northern countries potentially having an advantage over the much more divisive systems on the southern periphery. Accommodating macroeconomic policies, however, would run into trouble everywhere for two reasons. In tight labour markets, and with a radicalised Left, agreement to wage constraint became a threat to the legitimacy and the coherence of the Unions. Moreover, fiscal expansion in combination with the oil price shocks led to escalating current account deficits, except in Germany and the Netherlands, plus increasing budget deficits.

The commonly adopted solution consisted in increasing unemployment so as to restore the coherence of the system, but the way in which this was done differed quite radically. In the case of the Scandinavian countries and the UK, governments explicitly took the responsibility for this decision, arguing that the crisis resulted not from external factors, but from a failure in the domestic process of interest intermediation. In Britain the Conservative government of Margaret Thatcher declared outright war on the trade unions in 1978 and orchestrated a monetary crunch that led to unprecedented increase in unemployment. In 1982 a Danish conservative-liberal government decided to end the soft currency policy in reaction to the breakdown of wage moderation.

The fact that all four governments were able to successfully impose a new policy regime that explicitly denied that macroeconomic managements could 
unconditionally accept a full employment target had two important consequences for the future of monetary integration. First, the responsibility for the deteriorating economic situation was not placed at the door of globalisation or some alleged German dominance. Secondly the government's ability to regain control of the economy out of its own accord allowed for a more relaxed approach to exchange rates policy, leaving the option open to relax the constraint in future. Consequently none of these countries felt the need to join the eurozone.

In the hard-currency countries the policy of negotiated wage restraint in exchange for macroeconomic policy concessions was short-lived. Since the late sixties even Germany and the Netherlands had not proven immune to the Keynesian orthodoxy. Especially for social democratic parties, the idea of discretionary demand management could fill the void left by the abandonment of socialist ideas. Yet, the survival of Keynesian ideas had depended on their being in no need for such policies in the post-war economic environment in which overheating was the more relevant problem. ${ }^{4}$ Once put into practice, the results were disappointing as budget deficits and inflation rates frequently increased without boosting growth. Implemented by the first leftist coalitions of the post-war period, the meagre results of demand management in Germany and the Netherlands quickly gained these governments a reputation for economic incompetence and, under the successive centre-right governments, prompted a return to the traditional policies of competitiveness through wage restraint in combination with fiscal restraint. In Germany, for example, the fiscal policies adopted by the SPD-FDP coalition after the 1978 G7 summit quickly came to be considered a failure as they led to higher budget deficits and inflation rates and the first current account deficit since 1965. The SPD quickly lost its reputation for economic competence, which was one of the core reasons for the fall of the government in 1982.

Yet, the return to hard-currency mercantilism could have easily failed if the main European partners had stuck to a more expansionary policy that prioritised full employment instead of low inflation and fixed exchange rates. In that case the Bundesbank's tight policies would have provoked substantial appreciation of the Deutsche Mark (DM) and thus current account deficits instead of surpluses. It is no coincidence that shortly after the DM was revalued in October of 1969 , under pressure from the Bundesbank and the main trading partners but against the opposition of the Minister of Finance Franz Josef Strauß, the Minister of Economy Karl Schiller and substantial parts of German industry, Chancellor Willy Brandt proposed EMU at the Hague Council of December 1969. Indeed,

4 On the very limited importance of Keynesian demand management after 1945 see Bispham \& Boltho, 1982 and Hall, 1989, pp. 367-368. 
the problem was particularity acute for Germany. Because the DM had come to serve as a reserve currency, periods of dollar weakness provoked massive capital inflows and DM revaluation. As Jonathan Story (1999, p. 23) points out, US dollar weakness tended to redouble German efforts to tie the other European currencies into some kind of fixed exchange rate arrangement.

The core problem with Brandt's EMU proposal and all subsequent German plans for monetary integration was that it required other members to forego monetary autonomy. In the wake of the social unrest of May 1968 in France and the Hot Autumn of 1969 in Italy, neither country was prepared to do so. Similarly, in Spain, Portugal and Greece the consolidation of democracy after the end of military rule mandated growth policies so as not to rekindle a virulent left-right divide. Nor did the large economies outside of the EU, first and foremost the USA and the UK, show a willingness to adopt German-style policies while Japan continued to pursue a soft-currency mercantilism.

Pursuing more expansionary policies than the core countries around Germany inevitably would imply devaluation relative to the DM. However, such policies can only succeed with a disciplined system of wage-setting that prevents that the rise in import prices resulting from devaluation is fully passed on into wages. In neither of these countries was the highly fragmented and politicised industrial relations system able to provide such discipline with the result that a policy which ignored the exchange rate in order to stimulate growth would face the prospect of a runaway inflation. The same fragmentation and politicisation of the industrial relations system also explained why the attempt to buy wage restraint by means of fiscal concessions was unsuccessful. This constellation provoked repeated exchange crises which pushed governments towards restrictive policies. However, the polarisation and fragmentation of the political system failed to produce a consistent majority for such policies. Consequently, macroeconomic policies oscillated between expansionary phases in which central banks accommodated wage increases and public deficits, punctuated by bouts of tight money and budget consolidation (Lazaretou, 2003, pp. 27-29; Goodman, 1992, pp. 142-158).

In the end it proved possible to break this stalemate only in the 1980s with the help of the external anchor of a fixed exchange rate. The economic turmoil since the seventies did raise doubts about the wisdom of expansionary macropolicies, but the creation of a political majority proved possible only by invoking Europe and globalisation. The argument that there was no alternative to Europe, that is, to monetary integration and the acceptance of the SEA and Directive $88 / 361$, which abolished all exchange controls within the Union, consisted 
of four separate strands. First, integration was linked to the post-war project of economic modernisation, with the performance of the core countries cited as proof (Della Sala, 2004). Secondly, the argument for participating in fixed exchange rate regimes played heavily on national prestige. Having a weak currency and being left out of the various exchange rate arrangements was depicted as being relegated to second-class citizenship. Thirdly, globalisation was invoked to argue that in a world of liberalised financial markets there was no alternative to fixed exchange rates, conveniently ignoring that the reemergence of international financial markets had wrecked the Bretton Woods fixed exchange rate arrangement in favour of floating. Finally, Europe came to serve as a scapegoat on which to deflect the domestic opposition that frequently arose when defence of the parity would require particularly restrictive policies.

\section{The (in)vulnerability of hard-currency mercantilism}

Far from having come closer to a solution of their problems, after more than two years of reforms the southern periphery finds itself in a particularly tricky conundrum. After over a decade of deteriorating competitiveness the revival of investment activity, which is the prerequisite for growth, will require a decisive boost to the private sector. As the current internal devaluation strategy is clearly dysfunctional, the best way to do so would be external devaluation-that is, euro exit. Southern governments will resist this solution to the bitter end because of the fear that the problems of the 1970s will re-emerge, in the sense that distributional conflict in societies marked by deep cleavages and a tradition of clientelistic government may be uncontrollable without an anchor to Europe. Perversely, the political effects of the current strategy seem to make such an outcome in case of a euro exit more likely because they strongly contribute to a fragmentation of the polity (Minder, 2012). By 2012, the second and third most popular parties in Greece were the communist and the fascist whereas in Spain the crisis has evolved into a threat of the territorial integrity of the state. Only in Italy has the current crisis led to a more united and more broadly supported government since the formation of a technocratic cabinet under Prime Minister Mario Monti. Yet, as Monti has pointed out, to prevent the emergence of an antiEuropean majority which might eventually force a euro exit, more support from the northern countries is needed ('Monti warnt...', 2011). Increased demand in the core states would greatly contribute to this so as to allow for a reversal of current account position with less draconian austerity. In this perspective, German policy decisions hold the key to the future of Europe. 
Given the reluctance with which Germany has agreed to support Greece, and subsequently Portugal, Ireland and Spain, fears arose that the country, instead, would turn its back on Europe (Guérot \& Leonard, 2011). Indeed, the case for fiscal mismanagement in Greece is not hard to make (Featherstone, 2011), whereas the German response to the fiscal problems that arose in the wake of unification were tackled by a series of reform programmes, the most extensive one being the Agenda 2010 of the SPD-Green coalition in 2003-2004. Many Germans thus understandably gained the impression of being asked to foot the bill for the unwillingness of others to shoulder the hardships required to put the economy on an even keel. The mood in Germany seemed to be well characterised by the slogan "We don't need the PIGS, we have the BRICS". Although that view maybe widespread, the German government cannot act on it for economic and political reasons. A reintroduction of national currencies can only imply a rapid appreciation of the DM which would be disastrous for the German export sector. Moreover, the prospect of being held responsible for the breakup of one of the core projects of European integration would have been politically unacceptable to any German government but especially to chancellor Merkel who likes to place her European policy in the tradition of Konrad Adenauer. As, for example, Minister of Finance Wolfgang Schäuble has made unmistakably clear in October 2012, Germany will do everything to keep Greece in the euro area.

The German strategy thus focusses on keeping the GIIPS in the eurozone while trying to reduce their public deficits and restore creditworthiness by fiscal austerity and by rekindling growth through structural reforms. German economic history seemed to provide clear confirmation for the correctness of such strategy, from Ludwig Erhard's liberalisation after the 1948 currency reform and the Bundesbank's early insistence of the virtues of tight money to Agenda 2010.

The mistake in this reading of history was to ignore that hard-currency mercantilism had only succeeded for such a long time because of the willingness of the Southern EU members to tolerate a deterioration of their competitiveness, and that only the latters' need for a currency anchor allowed Germany to take a maximalist position in the negotiations from the "snake" to EMU and the SGP. It equally ignored that the Greek public debt could not have risen to the proportions it did, had it not been financed by, amongst others, German banks. Finally, that recipe ignored that the fiscal problem in Spain, Ireland and Portugal were largely the result and not the cause of the crisis (Vernengo \& Pérez-Caldentey, 2012).

As the IMF had found out more than a decade earlier, such "Washington Consensus" recipes frequently tend to aggravate a crisis. The failure of such 
strategies also in Europe, together with the threat to its exports from a breakup of the euro means that Germany is successively forced to abandon core tenets of its policy orientation. Adherence the "no bail-out clause" would have bankrupted Greece in 2010, implying its exit from the eurozone and major losses for (not only) German banks, and was thus quickly scuttled. The original expectation was that the first assistance package would suffice. Yet, Greece needed more assistance in October of 2011, which equally did not prove sufficient. A third package for Greece, and possibly a second package for Portugal and Spain, would not obtain a majority in the Bundestag because of opposition from the Liberal coalition partner FDP and from within the Bavarian CSU, who argue that the lack of success is due to unwillingness to consistently implement reforms.

Paradoxically, the effect of this opposition was that Germany had to agree breaking the taboo of the monetary financing of deficits. Austerity policies not only provoked a collapse of GDP but gave rise to at times bitter popular opposition. Both effects served to undermine confidence in the GIIPS countries threatening to set in train a cumulative process whereby higher interest rates further undermine economic prospects and thus further weaken confidence. Since it remained unacceptable to Germany to let Greece, and possibly Spain and Portugal go bankrupt, the solution consisted in having the ECB buy up potentially unlimited amounts of GIIPS bonds. Although this decision met with the opposition of Bundesbank president Jens Weidmann, the government has refused to support his position and has sought to stamp down on dissenting voices from the Bavarian CSU. No public outcry has resulted, mainly because there currently is no inflation problem and German voters are more concerned about the threat of unemployment than abstract discussion about the stability of the velocity of circulation.

Critical strains on the German model may instead easily develop once the public comes to realise that the correction of European imbalances will require Germany to accept current account deficits. The focus on competitiveness as the key to economic success implies a mercantilist zero-sum game understanding of international economic relations as competitiveness per definition can only improve relative to other countries. Successful internal or external devaluation strategies by the GIIPS countries would thus have to be considered a threat to the prosperity of the surplus countries. The German population might easily conclude that after making many sacrifices to improve competitiveness, now competitiveness would need to be sacrificed for the sake of European integration.

Social democratic think-tanks like the Friedrich Ebert Stiftung instead see an opportunity in the current situation as they advocate higher wage increases and 
a more equal income distribution in order to boost German growth and imports (Dauderstädt \& Dederke, 2012). Yet, apart from the question if the GIIPS countries are best placed to benefit from the growth of German demand, a highwage strategy may only have been feasible as long as it seemed that Germany was immune to the crisis. But with austerity spreading throughout the EU, the US still recovering from the 2008 meltdown, and growth rates in China falling, economic prospects have started to darken rapidly also for Germany as of the summer of 2012.

To prevent faltering growth rates and current account surpluses from sparking an internal devaluation race and to convince the German public that the correction of European imbalances will not undermine prosperity, a turn to a domestically driven growth model would indeed be necessary. With the fiscal room of manoeuvre constrained that would require, similar to the policies that eventually overcame the Great Depression (Eichengreen \& Temin, 2010), a decisive change in ECB priorities from fighting inflation to stimulating growth, combined with a re-regulation of financial markets that promotes productive as opposed to speculative investment. Such a regime change, however, would not only run counter to the core convictions of the current government and much of the opposition of SPD but would also be met with the concerted opposition of the German economics profession and thus will likely be resisted until the bitter end.

\section{Conclusion}

The most damaging effect of the common currency is that it has turned what should have been domestic debates about political priorities into recrimination between Member States. If any proof is needed that the European project is failing, it is the fact that Europeans have taken to calling each other PIGS again. Without a common currency, Germany would have needed to decide whether it prefers a super-hard currency at the expense of its export industry or would rather support the more expansionary monetary policy orientation of its larger neighbours. Without the euro, a sagging currency and the threat of being shut out of international financial markets would have required an ordering of domestic preferences some time ago in the southern periphery. Instead the blame game has erupted in full force in the eurozone and the much needed reforms in the southern countries lack legitimacy as long as they are being imposed by force from outside. 
If only for that reason, a breakup of the eurozone may have salutary consequences. Of course, such a strategy is not without risk. In 1932, Germany found itself in a situation where both leaving and remaining with the common currency of that time, the Gold Standard, appeared to have unacceptable consequences. After the devaluation of Britain in September 1931, defending the old parity would undermine the export industry whereas devaluation was considered coterminous with hyperinflation. The solution it adopted was to shield its economy from the international system and create an economic empire to the east that was more compatible with its preferences (Ahamed, 2010, pp. 477-484). In countries like Greece and Italy, on the other hand, inability to supersede clientelistic notions of governance in favour of a national strategy, in the extreme case, might end up in a failed state scenario.

But these possibilities seem remote. To surmise that current German politicians might contemplate repeating the errors of the 1930s would seem ludicrous. In times of emergency at least Italy and Portugal do seem capable of much more effective government. Rather the risk is that the core countries, whose government do not even wish to contemplate that growth might rest on something else than structural reform and international competitiveness will persist in their current policies. At that point the EU would have managed the amazing feat of re-enacting the Great Depression when European governments similarly drove their economies over the cliff in order to defend a dysfunctional fixed exchange rate regime (Eichengreen \& Temin, 2010). One thing is certain - the EU would not survive that.

\section{References}

Ahamed, L. (2010), Lords of Finance: 1929, the Great Depression and the Bankers Who Broke the World, London: Windmill Books.

Bispham, J. \& Boltho, A. (1982), 'Demand Management,' in A. Boltho (ed.) The European Economy: Growth \& Crisis, Oxford: Oxford University Press, pp. 289328.

Bonatti, L. \& Fracasso, A. (2012), A Germans'Dilemma: Save the Euro or Preserve Their Socio-economic Model? EconPapers, no. 1207, Department of Economics, University of Trento, Italy.

Dauderstädt, M. \& Dederke, J. (2012), 'Reformen und Wachstum Die deutsche Agenda 2010 als Vorbild für Europa?' WISO Direkt, June 2012, Bonn: Friedrich Ebert Stiftung. 
Della Sala, V. (2004), 'Maastricht to modernization: EMU and the Italian social state,' in A. Martin \& G. Ross (eds.) Euros and Europeans: Monetary Integration and the European Model of Society, Cambridge: Cambridge University Press.

'Monti warnt...' (2012), 'Monti warnt vor anti-europäischen Protesten in Italien,' Die Zeit, January 11, 2012.

Eichengreen, B. \& Temin, P. (2010), 'Fetters of gold and paper', Oxford Review of Economic Policy, vol. 26, no. 3, pp. 370-384.

Featherstone, K. (2011), 'The Greek sovereign debt crisis and EMU: a failing state in a skewed regime,' Journal of Common Market Studies, vol. 49, no. 2, pp. 193-217.

Flassbeck, H. (2009), Gescheitert: Warum die Politik vor der Wirtschaft kapituliert, Frankfurt am Main: Westend Verlag.

Goodman, J. B. (1992), Monetary Sovereignty: The Politics of Central Banking in Western Europe, Ithaca: Cornell University Press.

Guérot, U. \& Leonard, M. (2011), Die neue Deutsche Frage: Welches Deutschland braucht Europa? Policy Brief April 2011, European Council on Foreign Relations.

Hall, P. A. (1989), 'Conclusion: the politics of Keynesian ideas,' in P. A. Hall (ed.) The Political Power of Economic Ideas: Keynesianism Across Nations, Princeton: Princeton University Press, pp. 361-391.

Henning, C. R. (1994), Currencies and Politics in the United States, Germany and Japan, Washington D.C.: Institute for International Economics.

Joebges, H. (2010), 'Exporte um jeden Preis? Zur Diskussion um das deutsche Wachstumsmodell,' WISO Direkt, October 2010, Bonn: Friedrich Ebert Stiftung.

Judt, T. (2007), Postwar: A History of Europe Since 1945, London: Pimlico.

Krugman, P. (2012), 'Europe's Economic Suicide,' The New York Times, April 15, 2012.

Lazaretou, S. (2003), Greek Monetary Economics in Retrospect: The Adventures of the Drachma, Bank of Greece Working Paper, no. 2, 2003.

Minder, R. (2012), 'Austerity protests are rude awakening in Portugal,' The New York Times, October 14, 2012.

Story, J. (1999), 'Monetary Union, Economic Competition and Political Negotiation,' in D. Webber (ed.) The Franco-German Relationship in the European Union, London: Routledge.

Vernengo, M. \& Pérez-Caldentey, E. (2012), 'The euro imbalances and financial deregulation: a post Keynesian interpretation of the European debt crisis,' RealWorld Economics Review, no. 59, pp. 83-104.

Weisbrot, M. \& Ray, R. (2011), Latvia's Internal Devaluation: A Success Story? CEPR Report, December 2011, Washington D.C.: Centre for Economic and Policy Research. 